\title{
Chemotaxonomic approaches to nivalenol-producing Fusarium species Fn 2B by an application of restriction fragment analysis of DNA
}

\author{
Yo-ichi Sato*, Masayuki Suzuki*, Kiyomitsu Nemoto*, Yoshitsugu SugiurA* \\ and Yoshio UENo*
}

(Received May 30, 1997 ; Accepted Aug. 11, 1997)

佐藤 洋一*, 鈴木 理之*, 根本 清光*, 杉浦 義紹*, 上野 芳夫* :

DNA フラグメント解析からみた nivalenol 産生性 Fusarium sp. Fn 2B の化学分類

\begin{abstract}
Summary
A trial for chemotaxonomic analysis of toxigenic Fusarium species was performed by an introduction of restriction fragment length polymorphisms based on the selected DNA probes of Fusarium sp. Fn 2B strain, a well-known producer of trichothecene mycotoxins nivalenol and fusarenon-X. A total DNA of $F$. Fn 2B was prepared from the protoplast suspension of mycelia, digested with $B a m \mathrm{HI}$, and ligated into Bam HI site of plasmid vector pUC19. Two clones harboring inserts in sizes of approximately 1.1 and $1.7 \mathrm{~kb}$ were randomly selected for probes. Hybridization patterns of ${ }^{32} \mathrm{P}$-labeled 1.1 and $1.7 \mathrm{~kb}$ fragments of $\mathrm{Fn} 2 \mathrm{~B}$ with Bam HI, EcoRI or HindIII-digested DNAs from $F$. sporotrichioides (4 isolates), F. graminearum (6 isolates), F. tricinctum (4 isolates), $F$. poae (4 isolates), F. crookwellense (3 isolates) and others, were compared by Southern blots. The data obtained with the $1.1 \mathrm{~kb}$ fragment have revealed a similar pattern of restriction fragment profiles among the isolates of same Fusarium species such as $F$. sporotrichioides, $F$. tricinctum or $F$. graminearum. While, the fragment profile of Fn 2B strain did not correspond to that of all the other Fusarium spp. tested. This suggested that $F$. sp. Fn 2B, originally reported as $F$. nivale by Dr. Tsunoda and later cited as $F$. tricinctum at NRRL by J. J. Ellis and to F. sporotrichioides at the Medical Research Council Collection (MRC, Tygerberg, South Africa) by Marasas et al., may be unidentified Fusarium species.
\end{abstract}

Key words : nivalenol, trichothecenes, Fusarium species, restriction fragment length polymorphism

\section{Introduction}

Head blight diseases (scab, Akakabi-byo in Japanese) of wheat, barley and other cereal crops sporadically developed by infection of pathogenic Fusarium species in the world, and the consumption of these Fusarium-molded cereals by man and farm animals causes several food-borne diseases such as scabby wheat toxicosis in Japan, Korea and China, scabby corn intoxication and hyperestrogenism in the U. S., alimentary toxic aleukia (ATA) in Russia, and equine leukoencephalomalacia in South Africa. Extensive researches have identified numerous Fusarium mycotoxins such as the trichothecenes, zearalenone, moniliformin, fumonisins and others, as

* Department of Toxicology and Microbial Chemistry, Faculy of Pharmaceutical Sciences, Science University of Tokyo (Ichigaya, Shinjuku-ku, Tokyo 162)

東京理科大学薬学部毒性学・微生物化学教室（T162 東京都新宿区市ヶ谷船河原町 12） 
reviewed by the author ${ }^{1,2,3)}$, Nelson et al. ${ }^{4)}$, Marasas et al. ${ }^{5)}$ and Lacey ${ }^{6}$.

Historically speaking, Tsunoda et $a l^{7)}$, isolated first several toxigenic Fusarium species in 1963 from scabby wheat harvested in Kumamoto Prefecture, a southern part of Japan, where serious scab developed after heavy precipitation, and he identified one of these strains $F$. sp. Fn 2 (deposited as NRRL 9509) to $F$. nivale by comparison with the reference strain $F$. nivale NRRL 3249 identified by J. J. Ellis. Later, this strain was cited as $F$. tricinctum (Corda) Sacc. at NRRL and to F. sporotrichioides Sherb by W. F. O. Marasas et al. ${ }^{5}$. From the following evidences that (1) the trichothecene mycotoxins and their producers were grouped to the type (A) (T-2 toxin, diacetoxyscirpenol DAS et al. from $F$. sporotrichioides, $F$. poae etc) and the type (B) (nivalenol NIV, deoxynivalenol DON et al. from $F$. graminearum etc $)^{8)}$, (2) Fn 2B is well known as a potent producer of $\mathrm{NIV}^{9)}$ and fusarenon-X (FX, 4-acetyl-NIV) ${ }^{10)}$ which contaminates cereals and food worldwide $^{11)}$, and (3) the taxonomic situation of Fn 2B based on classical morphology is still confusing, we have tried to clarify the taxonomic character by an introduction of chemotaxonomic approaches. At present, several methods such as soluble protein electorophoretic pattern, zymograms, monoclonal antibody reaction, immunoelectrogram and ribosomal proteins analysis are reported. In this experiment, we have adopted restriction fragment analysis of DNA. The data revealed that the isolate $F$. sp. Fn 2B is different from the toxigenic Fusarium species examined, suggesting an undescribed Fusarium species.

A part of present data was reported as a preliminary form ${ }^{12}$.

\section{Materials and Methods}

Fungi : Fusarium isolates used in this experiment were obtained from our stock cultures, except F. nivale ARC 1035 and 2051 provided by Dr. Koizumi (Agricultural Research Center, the Ministry of Agriculture, Forestry and Fisheries, Tsukuba). The isolates were cultured on potato-dextose agar (PDA) slants at $27^{\circ} \mathrm{C}$ for 7-10 days before use. Species and strains numbers

Table 1 Test strains of Fusarium species

\begin{tabular}{|c|c|c|c|c|c|}
\hline${ }^{* 1}$ Section & Species & $\begin{array}{l}\text { Major } \\
\text { trichothecenes }\end{array}$ & & Strains & \\
\hline \multirow{6}{*}{$\begin{array}{l}\text { Arachnites } \\
\text { Sporotrichiella }\end{array}$} & F. nivale & \multirow[b]{2}{*}{$\mathrm{T}-2$} & ARC 1035 & \multicolumn{2}{|c|}{ ARC 2051} \\
\hline & F. poae & & $\begin{array}{c}\mathrm{KF} 1103 \\
\mathrm{R} 2356\end{array}$ & R 2145 & R 2344 \\
\hline & F. tricinctum & $\mathrm{T}-2$ & R 2000 & R 2010 & R 2071 \\
\hline & F. sporotrichioides & $\mathrm{T}-2$ & $M-1-1$ & R 2017 & R 2153 \\
\hline & & & $\mathrm{R} 2301$ & & \\
\hline & $F$. fusarioides & $\mathrm{T}-2$ & $\mathrm{R} 2127$ & & \\
\hline \multirow[t]{5}{*}{ Discolor } & F. crookwellense & NIV & KF 233 & KF 871 & $\mathrm{R} 2166$ \\
\hline & F. culmorum & $\mathrm{DON}$ & KF 98 & R 2150 & \\
\hline & F. graminearum & DON/NIV & KF 208 & KF 205 & R 2118 \\
\hline & & & $\mathrm{OK}-1-1$ & TH-5-1 & TY-1-1 \\
\hline & F. sambucinum & DAS & $\mathrm{R} 2289$ & $\mathrm{R} 2291$ & \\
\hline unidentified & F. sp. & NIV & Fn 2 B & & \\
\hline
\end{tabular}

${ }^{* 1}$ This section is based on the system of Booth (1971). 
were listed in Table 1, along with their major trichothecenes reported.

Production of trichothecenes : Each isolates were cultured in $100 \mathrm{ml}$ Erlenmeyer flasks, each containing $10 \mathrm{~g}$ of polished rice grains previously immersed in tap water for one hr and supplemented with $5 \mathrm{ml}$ of $3 \%$ peptone solution, at $25^{\circ} \mathrm{C}$ for one week. The moldy rice cultures were homogenized in acetonitrile-water $(3: 1)$, and the contents of trichothecenes in the filtrate were estimated by gas chromatography (GC) after clean-up over Florisil column ${ }^{13)}$.

Preparation of fungal DNA and hybridization: The test strains were cultured by reciprocal shaking at $25^{\circ} \mathrm{C}$ for 3-4 days in Sakaguchi flasks each containing $100 \mathrm{ml}$ of Czapek Dox medium supplemented with $0.2 \%$ yeast extract. The mycelial mass suspended in $1.2 \mathrm{M} \mathrm{KCI}$ solution was digested with $0.5 \%$ Novozyme 234 (Novo BioLabs, Bagsvaad, Denmark) at $25^{\circ} \mathrm{C}$ for $2-3 \mathrm{hr}$. The protoplasts harvested were incubated in PK buffer $(100 \mathrm{mM}$ Tris HCI buffer, $\mathrm{pH}$ 8.0, $12.5 \mathrm{mM}$ EDTA, $150 \mathrm{mM} \mathrm{NaC1}, 1.0 \% \mathrm{SDS}, 1 \mathrm{mg} / \mathrm{ml}$ pronase) at $37^{\circ} \mathrm{C}$ for $3 \mathrm{hr}$, and DNA was extracted.

Construction of DNA library, Southern blots and hybridization were performed according to standard protocols, briefly as follows: the genomic DNA of Fn 2B was digested with Bam HI, and the fragments were ligated into the Bam HI sites of plasmid vector pUC19 by use of ligation kits containing T4 DNA ligase (Takara Shuzo, Kyoto). After transforming E. coli JN109 by calcium chloride procedure, plasmid DNA was isolated, digested by Bam HI, and after electrophoresis in $1.5 \%$ agarose gel, inserted DNA fragments were prepared by the Gene clean ${ }^{\mathrm{TM}} \mathrm{Kit}$ (Bio 101, C. A.) and labeled with ${ }^{32} \mathrm{P}$ using multiprime DNA labeling system (Amersham, U. A. ). Each $2 \mu \mathrm{g}$ of genomic DNA were digested with Bam HI, Eco RI, or HindIII (Nippon Gene, Tokyo), and separat-

Table 2 Production of trichothecenes by Fusarium

\begin{tabular}{|c|c|c|c|c|}
\hline \multirow[b]{2}{*}{ Species } & \multirow[b]{2}{*}{ Strain } & \multicolumn{3}{|c|}{ Production of trichothecenes (ppm) } \\
\hline & & NIV type ${ }^{a)}$ & DON type ${ }^{\text {b) }}$ & T-2 type ${ }^{\mathrm{c})}$ \\
\hline \multirow[t]{2}{*}{$F$. poae } & KF 1103 & n. d. ${ }^{\text {d) }}$ & n. d. & 4.17 \\
\hline & $\mathrm{R} 2356$ & n. t.e) & n. t. & n. t. \\
\hline \multirow{2}{*}{ F. sporotrichioides } & R 2017 & n. d. & n. d. & 3.57 \\
\hline & $\mathrm{R} 2301$ & n. d. & n. d. & 292.2 \\
\hline F. fusarioides & R 2127 & n. $d$. & n. d. & 8.86 \\
\hline \multirow[t]{2}{*}{ F. tricinctum } & $\mathrm{R} 2000$ & n. d. & n. d. & 5.83 \\
\hline & R 2010 & n. d. & n. d. & 299.7 \\
\hline \multirow[t]{2}{*}{ F. crookwellense } & KF 233 & 0.52 & n. d. & n. d. \\
\hline & KF 871 & n. t. & n. t. & n. t. \\
\hline \multirow[t]{2}{*}{ F. culmorum } & KF 98 & n. d. & 8.01 & n. d. \\
\hline & $\mathrm{R} 2150$ & n. d. & 0.10 & n. d. \\
\hline \multirow[t]{3}{*}{ F. graminearum } & KF 250 & n. d. & 30.2 & n. d. \\
\hline & KF 208 & n. d. & 6.86 & n. d. \\
\hline & TY $-1-1$ & 0.14 & 2.05 & n. d. \\
\hline$F . s p$ & Fn 2B & 194 & n. d. & n. d. \\
\hline
\end{tabular}

a) NIV type : NIV and 4-AcNIV

b) DON type : DON, 3-AcDON or 15-AcDON

c) T-2 type : T-2 or DAS

d) n. d. : not detected (below $10 \mathrm{ppb}$ )

e) n. t. : not tested 
ed by electrophoresis in $0.7 \%$ agarose gel. DNA was transferred to nylon membranes (Hybond$\mathrm{N}$, Amersham). The blots were hybridized to ${ }^{32} \mathrm{P}$-labeled probes at $42^{\circ} \mathrm{C}$ under stringent condition $(50 \%$ formamide, $6 \times \mathrm{SSC})$ and washed. Autoradiography on X-OMAT films was performed at $-70^{\circ} \mathrm{C}$ with intensifying screens.

\section{Results and Discussion}

In agreement with the previous findings ${ }^{8,14,15)}, F$. sporotrichioides, $F$. poae, $F$. fusarioides and $F$. tricinctum produced the type (A) trichothecenes, and $F$. crookwellence, $F$. sp. Fn $2 \mathrm{~B}$ and $F$.
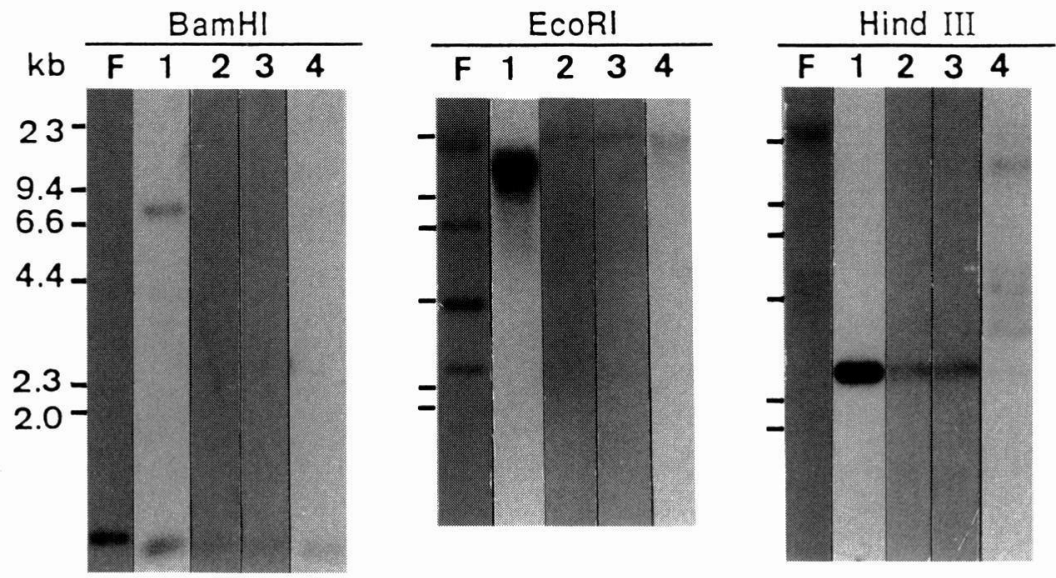

$\begin{array}{lllll}F: F n-2 B & \text { 1:KF } 1103 & \text { 2:R } 2145 & \text { 3:R } 2344 & \text { 4:R } 2356\end{array}$

(A) F.poae

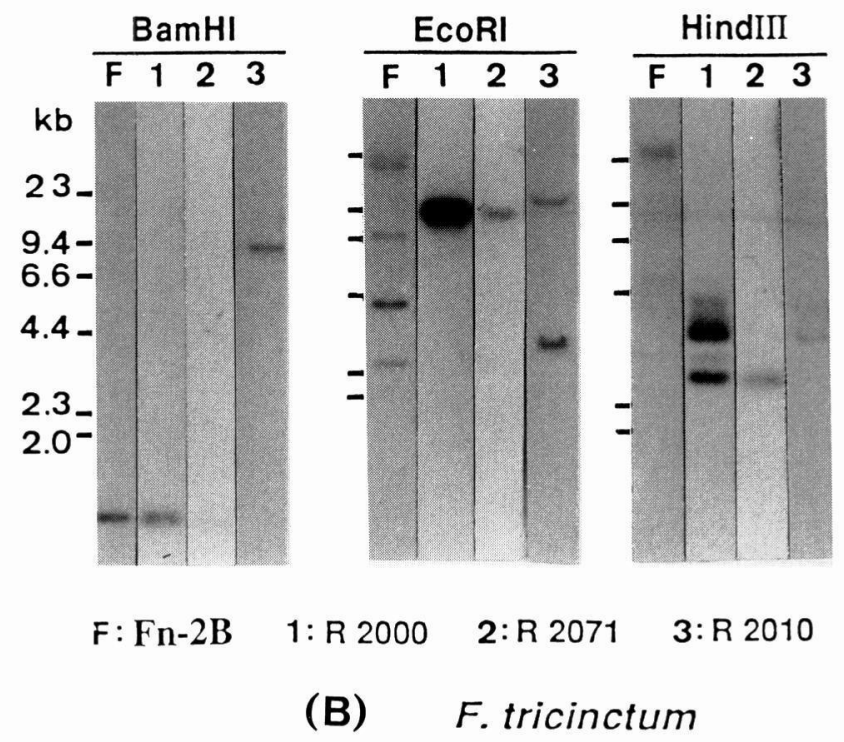

Fig. 1. Hybridization patterns of fungal DNA with $1.1 \mathrm{~kb}$ fragment of Fn 2B. 
graminearum produced the type (B) (Table 2).

For the isolation of genomic DNA from Fusarium spp., the present method is simple and rapid, and yielded 60 (R2334)-900 (R2071) $\mu \mathrm{g}$ of DNA per gram of the wet mass of protoplasts, with a size greater than $100 \mathrm{~kb}$ and $\mathrm{A}_{260 / 280}$ ratio of 1.6-2.0. Upon insertion of Bam HI fragments of the total DNA genome of Fn 2B into BamHI sites of E. coli plasmid vector pUC19, followed by an introduction of the plasmids into E. coli JM109, two colonies were selected from the transformants. The Bam $\mathrm{HI}$ digestion of plasmids revealed two fragments with 1.1 and $1.7 \mathrm{~kb}$.

Southern blot analysis on the selected Fusarium spp. with $1.1 \mathrm{~kb}$ fragment of $\mathrm{Fn} 2 \mathrm{~B}$ as a probe was shown in Fig. 1 (A)-(D), and the detailed results on each isolates were schematically
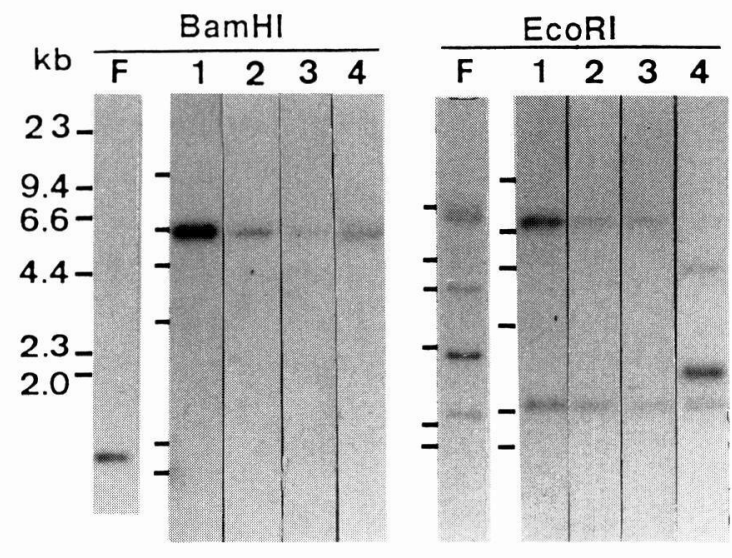

$\mathrm{F}: \mathrm{Fn}-2 \mathrm{~B}$

1: $M-1-1$

2: R 2153

\section{(C)}
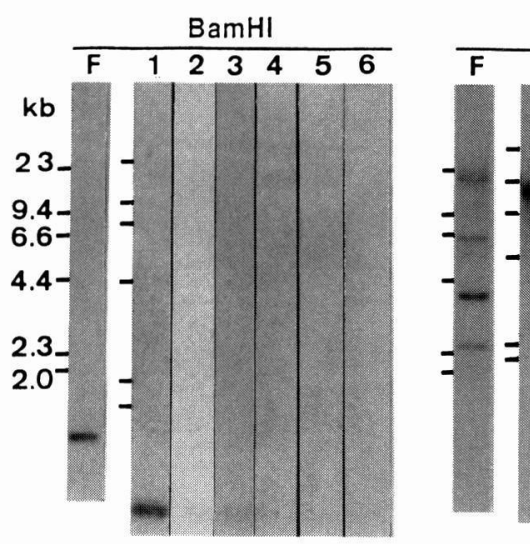

$F: F n-2 B$

$1: K F 208$

2:KF250

(3:

3: R 2301

4: R 2017

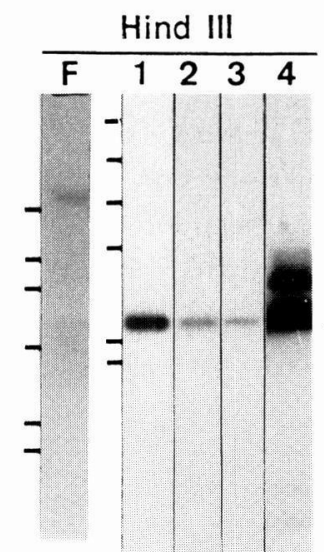

\section{(D) F. graminearum}

Fig. 1. Hybridization patterns of fungal DNA with $1.1 \mathrm{~kb}$ fragment of Fn 2B. 
presented in Fig. 2. The data on $F$. nivale and $F$. sambucinum were not presented since no notable bands were detected. The results showed that the restriction fragment patterns of Fn $2 \mathrm{~B}$ were markedly different from those of the Fusarium spp. tested.

However, there are common patterns among the same species of selected Fusarium species, as follows; In all 4 isolates of $F$. poae, Bam HI yielded the band at $0.9 \mathrm{~kb}$, along with an additional band at $7 \mathrm{~kb}$ in KF 1103 and R 2356, and the band at $2.5 \mathrm{~kb}$ was common after the digestion with Hind HI. In the two isolates (R2000 and R2071) of F. tricinctum, the fragments with $0.9,8$ or 2.5 $\mathrm{kb}$ were detected after Bam HI, Eco RI and HindIII, respectively. In F. sporotrichioides, these three restriction enzymes resulted in $8,2.5$ and $10.3 \mathrm{~kb}$, and in $F$. graminearum $0.9,8.5$ and $2.5 \mathrm{~kb}$ were the common bands, respectively.

Since the Southern blots with the $1.1 \mathrm{~kb}$ fragment revealed various hybridization patterns among the DNA derived from the Fusarium species, it was presumed that this fragment may be highly conserved and code some common genes essential for the fungal growth. However, the sequence analysis of this $1.1 \mathrm{~kb}$ fragment estimated to compose $1,149 \mathrm{bp}$ in length, and computer search resulted in no information about already known-genes and proteins.

Southern blot analysis with the $1.7 \mathrm{~kb}$ fragment revealed the bands at $1.7 \mathrm{~kb}, 9.4 \mathrm{~kb}$ and $4.5 \mathrm{~kb}$ in Fn 2B after the digestion with Bam HI, EcoRI and HindIII, respectively. But no significant hybridization pattern was observed with the DNA fragments derived from the selected Fusarium

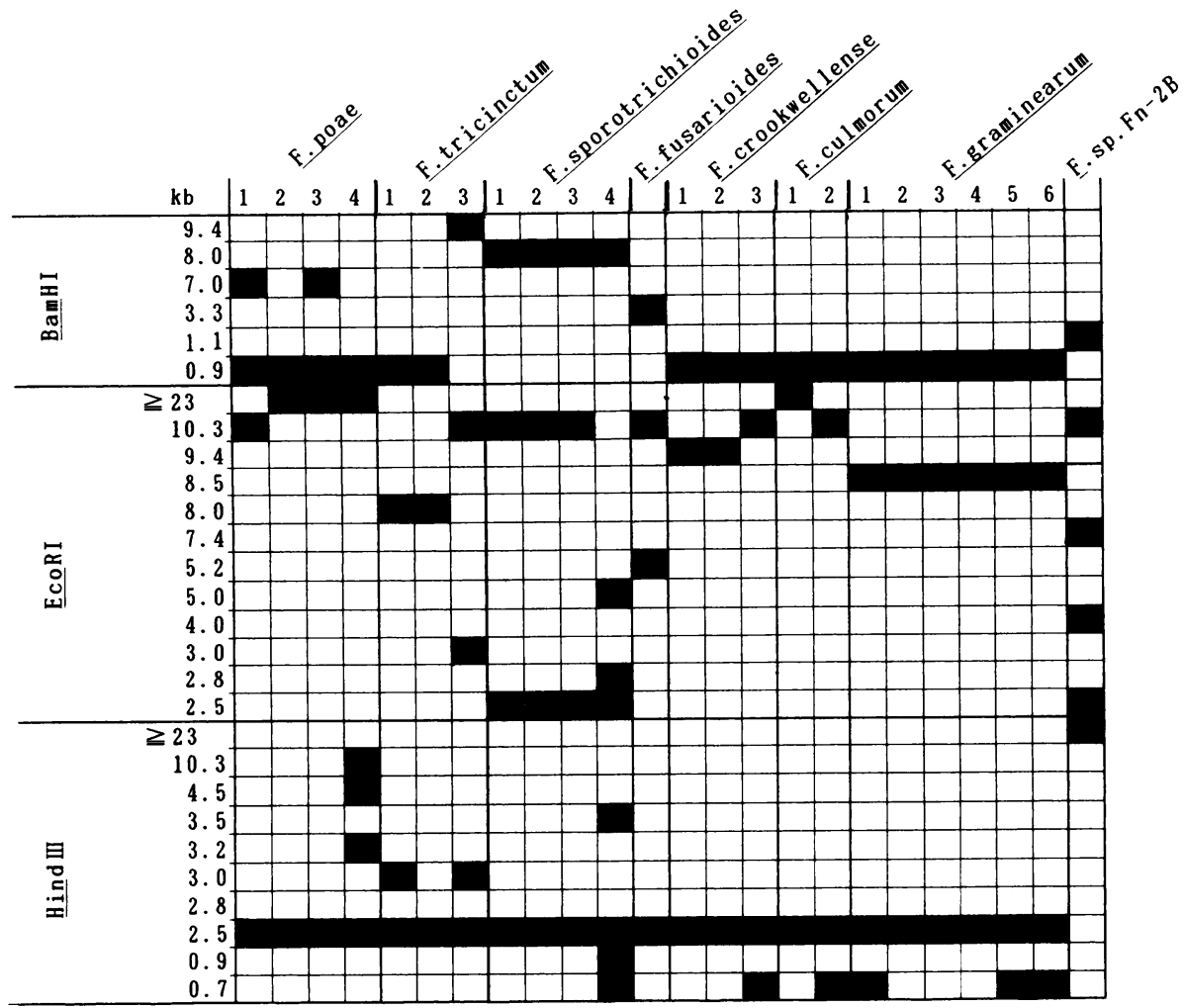

Fig. 2. Schematic presentation of hybridization patterns of fungal DNA with $1.1 \mathrm{~kb}$ fragment of Fn $2 B$. 
spp. (data not presented).

From the present data shown in Fig. 2 with $1.1 \mathrm{~kb}$ fragment of Fn 2B, it was demonstrated that there are common restriction fragment length patterns among the same species, and no such similar patterns were detected amonts the different species. It means that this $1.1 \mathrm{~kb}$ fragment is expected as an excellent tool for the classification of trichothecene-producing fungi. An important finding is that the hybridization pattern observed with $\mathrm{Fn} 2 \mathrm{~B}$ is unique among the toxigenic Fusarium species tested. It suggested that $\mathrm{Fn} 2 \mathrm{~B}$ is unique among the toxigenic Fusarium species tested. It means that $\mathrm{Fn} 2 \mathrm{~B}$ is an undescribed Fusarium species.

Recently, we have determined the primary structure of peptidyl-isomerase a (PPIase) in $F$. sporotrichioides ${ }^{16,17,18)}$. This enzyme, known as a cyclophilin, plays an important role for cis-trans isomerization of prolyl peptide bonds in polypeptides and the folding process of proteins. Further, PPIase constitutes a highly conserved family of abundant proteins in eukaryotes. In this respect, such information on the amino acid sequence of selected fungal proteins is expected to give a tool for chemotaxonomy of Fusarium species in future.

Acknowledgements A part of the present experiments was aided by the Ministry of Education, Science and Culture and the Ministry of Agriculture, Forestry and Fisheries (Japan). The strains F. nivale ARC 1035 and 2051 were kindly provided by Dr. Koizumi (Agricultural Research Center, the Ministry of Agriculture, Forestry and Fisheries, Tsukuba).

\section{References}

1) Ueno, Y.: Adv. Nutr. Res., Vol. 3, Plenum, p. 301 (1980).

2) Ueno, Y. (Ed. ): Trichothecenes: Chemical, Biological and Toxicological Aspects. Elsevier (1983).

3) Ueno, Y.: Trichothecenes in Food (Ed. K. Miller), Academic Press, p. 123 (1987).

4) Nelson, P. E., Toussoun, T. A. and Cook, R. J. (Eds. ): Fusarium: Diseases, Biology and Taxonomy, Pennsylvania State Univ. Press (1981).

5) Marasas, W. F. O., Nelson, P. E. and Toussoun, T. A.: Toxigenic Fusarium Species: Identity and Mycotoxicology, Pennsylvania State Univ. Press, p. 53 (1984).

6) Lacey, J. (Ed. ): Trichothecenes and other Mycotoxins, John Wiley and Sons (1985).

7) Tsunoda, H., Toyasaki, M., Morooka, M., Nakano, N., Yoshiyama, T., Ohkubo, K. and Isoda, M, : Bull. Natl. Food Res. Inst. 23, 89 (1968).

8) Ueno, Y., Sato, N., Ishii, K., Sakai, K., Tsunoda, H. and Enomoto, M. : Appl. Microbiol., 25, 699 (1973).

9) Tatsuno, T., Saito, M., Enomoto, M. and Tsunoda, H.: Chem. Pharm. Bull., 16, 2519 (1968).

10) Ueno, Y., Ishikawa, Y., Saito-Amakai, K. and Tsunoda, H. : Experientia, 25, 1062 (1970).

11) Tanaka, T., Hasegawa, A., Yamamoto, S., Lee, U. -S., Sugiura, Y. and Ueno, Y. : J. Agric. Food Chem., 36, 979 (1988).

12) Sato, Y., Suzuki, M., Nemoto, K. Sugiura, Y. and Ueno, Y.: Abst. 32nd Meet. Jpn. Assoc. Mycotoxicol. (Tokyo), p. 9 (1991).

13) Sugiura, Y., Watanabe, Y. Tanaka, T., Yamamoto, S. and Ueno, Y.: Appl. Environ. Microbiol. 56, 3047 (1990).

14) Sugiura, Y., Fukasaku, K., Tanaka, T., Matsui. and Ueno, Y.: Appl. Environ. Microbiol., 59, 3334 (1993).

15) Sugiura, Y., Saito, H., Tanaka, T., Ichinoe, M. and Ueno, Y.: Mycosci., 35, 77 (1994).

16) Fukaya, N., Chow, L-P., Sugiura, Y., Tsugita, A., Ueno, Y. and Tabuchi, K. : J. Biomed. Sci., 2, 353 (1995).

17) Chow, L-P., Tsugita, A., Sugiura, Y. and Ueno, Y.: Mycotoxins, 43, 37 (1996).

18) Chow, L-P., Kamo, M., Ueno, Y. and Tsugita, A.: Natural Toxins, 4,149 (1996).

19) O'Donnell, K. : Mycotoxins, 45, 1 (1997). 


\section{Addendum}

By an introduction of multifocus analysis, phylogenic approach on toxigenic Fusarium spp. carried out by K. O'Donnell demonstrated that the isolate of Fn series (Fn 2, Fn 2B, Fn M) is undescribed species, and given a novel name Fusarium kyushuiense D'Donnell \& Ueno sp. nov ${ }^{19}$. This finding supported our present finding obtained by DNA fragment hybridization. 